\title{
Rapid Detection of Milk Protein based on Proteolysis Catalyzed by Trypsinase
}

\author{
Yafeng Chen \\ Institute of Food Quality and Safety, University of Shanghai for Science and Technology \\ Shanghai 200093, China \\ Email:cyfxy0498@126.com
}

Received: December 27, 2010

Accepted: January 25, 2011

doi:10.5539/mas.v5n2p82

\begin{abstract}
Using pH-state method, when degree of casein hydrolysis was set as criterion, the optimal enzymatic reaction conditions were obtained as follows: $\mathrm{pH} 7.5$ and temperature $55{ }^{\circ} \mathrm{C}$. Based on the proteolysis catalyzed by trypsinase, the relationship between protein content $(\mathrm{x})$ and initial velocity of enzymatic reaction $(\mathrm{y})$ was discussed and the equation of $\mathrm{y}=0.1177 \mathrm{x}\left(\mathrm{R}^{2}=0.9927\right)$ was found as standard curve for the calculation of protein content. In addition, the protein contents in five kinds of commercial fresh milk were determined by enzyme hydrolysis method and GB method (biuret method). Protein content calculated by enzyme hydrolysis method could be confirmed by GB method and the analysis of t-test indicated that there was no notable difference between two methods. Furthermore, the determinate time of the rapid method was only 8 minutes (including samples' preparation) and was $1 / 20$ times than that of biuret method.
\end{abstract}

Keywords: Protein, Trypsinase, The initial velocity, PH-state

Nutrient-rich milk is the ideal natural food, protein is one of the major nutritional components of milk, which also is an important quality indicator of a large number of dairy products (LIU Dong-hong,TANG Jia-ni,LV Yuan, YE Xing-qian, 2008). However, in recent years, "Big Head" and "melamine" event happened time to time. They also reflected the existence of significant gaps in dairy testing (TANG Jia-ni, LV Yuan,FU Yu, YE Xing-qian, LIU Dong-hong, 2009), so how to detect the protein content of dairy products quickly and accurately, has restricted the development of China's dairy industry.

The nitrogen content of milk divides into non-protein nitrogen and true protein (Depeters EJ, Ferguson JD, 1992). Protein content in milk is currently detected by the main methods for Kjeldahl method, Coomassie Brilliant Blue G-250 method, biuret, etc(QIN Li-hu, KOU Yun-juan, REN Jiang-hong, SUN Wu-bin, 2001)( TANG Ping, TIAN Jing, SHE Zhen-bao, WENG Qian-feng, XU Guo-wang, 2006)( ZHANG Ai-mei, LI Lin-wei, ZANG Yu-bo, 2006). But these methods both have complicated operation, consumption of reagents and more in need of special equipment or material. Therefore, we use enzymatic reaction with the relations between the substrate concentration and the initial velocity, and then establish a rapid detection method of true protein in milk. When we test samples, only need to measure the initial velocity of hydrolysis then can get the true protein content, in the meanwhile because this method is used to detect the true protein, so it also can prevent unscrupulous trader's adulterate melamine into milk.

\section{Materials and methods}

\subsection{Materials and reagents}

Carbon tetrachloride, potassium sodium tartrate, trichloroacetic acid, anhydrous sodium carbonate, disodium hydrogen phosphate, sodium dihydrogen phosphate, anhydrous copper sulfate, sodium hydroxide, barium hydroxide, zinc sulfate, Folin - phenol reagent, trypsin were purchased from China National Medicines Corporation Ltd. Casein were purchased from National Institutes for Food and Drug Control.

\subsection{Experimental methods}

\subsubsection{Folin-phenol method to measure trypsin activity}

Determination of trypsin activity was reference to Wang Furong (GUO Yong, 2002)( WANG Fu-rong,PANG Yu-zhen, 1981) and others methods, the measured tyrosine (y) and absorbance (x) of the standard curve was $y=$ $0.009 \mathrm{x}\left(\mathrm{R}^{2}=0.9927\right), \mathrm{K}$ was $111.11 \mu \mathrm{g} / \mathrm{OD}$. Activity Definition: In the above measurement conditions, we use the amount of enzyme which produces $1 \mu \mathrm{g}$ tyrosine per minute needed as a unit. Therefore, the obtained activity of trypsin used for the $57.33 \mathrm{u} / \mathrm{mg}$. 


\subsubsection{Determination of protein degree of hydrolysis ( $\mathrm{DH} \%)$ by $\mathrm{pH}$-state method}

The degree of hydrolysis was determined by pH-state method (MA Ge-li, PENG Xin-bang, WEI Jun, MA Tian-hua, 2007), when hydrolysis begins, adjust the $\mathrm{pH}$ of the reaction system as $\mathrm{pH}$ value "a" (a for each of the initial reaction $\mathrm{pH}$ ), then add $0.1 \mathrm{~mol} / \mathrm{L} \mathrm{NaOH}$ solution into system to adjust $\mathrm{pH}$, the $\mathrm{pH}$ values remain at the setting value "a", recording the volume of $\mathrm{NaOH}$ which used in reaction after 15 mins. Optimized $\mathrm{pH}$ values, "a" set 7.0,7.5,8.0,8.5 and 9.0; optimized temperature, "a" was set to 7.5.

\subsubsection{Determination of the initial velocity of hydrolysis of proteins by $\mathrm{pH}$-state method}

The concentration of casein solution were prepared $6.60,8.25,11.00,16.50,33.00 \mathrm{mg} / \mathrm{ml}$, use $\mathrm{pH}$-state method to detect the initial velocity of enzyme reaction.

Take $30 \mathrm{ml}$ casein solution, make the temperature constantly at $55^{\circ} \mathrm{C}$ for $3 \mathrm{~min}$, then take another $0.1 \mathrm{~mol} / \mathrm{L}$ $\mathrm{NaOH}$ standard solution to adjusting $\mathrm{pH}$ into 7.50 , add $171.99 \mathrm{u}$ trypsin, immediately recording time. When the $\mathrm{pH}$ value decreased 0.05 , transferred back to $\mathrm{pH} 7.50$ with standard $\mathrm{NaOH}$ solution, repeat the experiment for 5 times, recording the reaction time $\mathrm{t}(\mathrm{s})$ and consumption volume $\mathrm{v}(\mu \mathrm{l})$ each time, according to above records to make a figure, the slope is the initial velocity of hydrolysis $\mathrm{V}(\mu \mathrm{l} / \mathrm{s})$. According to the casein concentration and its corresponding initial velocity, we can get their curve.

\subsubsection{Determination of the protein content of milk samples by enzymatic hydrolysis}

Take fresh milk samples A, B, C, D, E, the samples were diluted three times, and then detect the initial velocity of hydrolysis, took them into 1.2.3 curves obtained, respectively, then we can get the protein content of them.

\subsubsection{Statistical analysis}

The Data for each experiment were the average of three parallel, and limited the upper and lower error in figures. Using Enzyme initial velocity method to measure out the protein content of milk samples, then compare with the samples which was detected by biuret method. And used paired t-test method to judge whether the results of two methods were significantly different.

\section{Results and Analysis}

\subsection{Optimize the condition of trypsin catalyzed hydrolysis of casein}

\subsubsection{The effect of $\mathrm{pH}$ on the degree of hydrolysis of casein}

According to researches on the conditions of trypsin hydrolysis from Li Peijun (LI Pei-jun, YUAN Yong-jun, HU Ting, WANG Li-hui, 2005), Li Guiqin (LI Gui-qin, LIU Jin, HAN Qing-bo, 2003), we take 30ml $33.00 \mathrm{mg} / \mathrm{ml}$ casein solution and adjust $\mathrm{pH}$ to $7.0,7.5,8.0,8.5$ and 9.0 , enzyme volume of $57.33 \mathrm{u}$, reaction at $45{ }^{\circ} \mathrm{C}$ for $15 \mathrm{~min}$, obtained $\mathrm{pH}$ values under different degree of hydrolysis, the results shown in Figure 1.

It can be seen from Figure 1, when $\mathrm{pH}$ between 7.0 and 8.0, the maximum degree of hydrolysis at $\mathrm{pH} 7.5$ when the degree of hydrolysis of proteins was $2.17 \%$. Therefore, we selected the optimal hydrolysis $\mathrm{pH} 7.5$.

\subsubsection{The effect of temperature on the degree of hydrolysis of casein}

According to the research on trypsin hydrolysis of casein temperature at $\mathrm{pH} 7.5$ from Wang zheng (WANG Zheng, YANG Guo-yu, PANG Yu-shan, 2005), we take $30 \mathrm{ml} 33.00 \mathrm{mg} / \mathrm{ml}$ casein solution, enzyme amount was $57.33 \mathrm{u}$, set temperature at $35{ }^{\circ} \mathrm{C}, 40{ }^{\circ} \mathrm{C}, 45{ }^{\circ} \mathrm{C}, 50{ }^{\circ} \mathrm{C}, 55{ }^{\circ} \mathrm{C}$ and $60{ }^{\circ} \mathrm{C}$, reaction of $15 \mathrm{~min}$, obtained the degree of hydrolysis of casein in different temperatures, the results shown in Figure 2.

It can be seen from Figure 2 that the minimum degree of hydrolysis of proteins at $35^{\circ} \mathrm{C}$; and then with increasing temperature, the speed gradually accelerated enzymatic hydrolysis, the maximum degree of hydrolysis at $55^{\circ} \mathrm{C}$ when the degree of hydrolysis of $2.39 \%$. Then with the temperature increasing, the degree of hydrolysis of casein decreased. So choose the best hydrolysis temperature was $55^{\circ} \mathrm{C}$.

\subsection{Analysis of the relation between the concentration of Initial velocity and casein hydrolysis curves}

We got the corresponding initial velocity and relative standard deviation (RSD) under the different casein concentration, as shown in Table 1.

As can be seen from Table 1, with the (casein) concentration of substrate increasing, the initial velocity of enzymatic reaction was also increasing. According to the general concepts of enzyme kinetics, enzyme and substrate binding for single-substrate reaction, if the enzyme concentration and other reaction conditions constant, we can get rectangular hyperbola between the reaction rate (velocity, V) and substrate concentration [S]. This curve can be roughly divided into three stages: a. When $[\mathrm{S}]$ is low, $\mathrm{V}$ with [S] increased linearly; b. with [S] continues to increase, the magnitude of increase in declining order reaction was mixed; c. When [S] up to a 
certain extent, we gain the maximum rate (maximum velocity, Vmax) and this time as a zero order reaction (JIA Hong-ti. 2005).

It is assumed measuring $\mathrm{V}$ meeting the Michaelis curve at the concentration of casein $0-33 \mathrm{mg} / \mathrm{ml}, \mathrm{do} 1 / \mathrm{V}-1 /[\mathrm{S}]$ of the double reciprocal graph, the curve should be a straight line. Of $1 / \mathrm{V}$ (y) and $1 /$ [S] (x) plot, the curve equation was $y=8.166 \mathrm{x}+0.0043\left(\mathrm{R}^{2}=0.9858\right)$, the line with assumptions, but fitness was not very good, may be casein was chosen for the concentration of too concentrated, leading to the error. Therefore, we get the $\mathrm{V}$ and [S] a direct linear relationship, shown in Figure 3, can be seen from the figure, the curve of the linear relationship, and the fitness greater than the double reciprocal curves, so I chose it as a standard curveto calculate the enzyme hydrolysis of the protein content.

\subsection{Determination of the protein content of milk samples with enzymatic hydrolysis method}

Select 5 different brands of fresh milk samples by enzymatic hydrolysis measured the initial velocity, bring them into the linear equation $\mathrm{y}=0.1177 \mathrm{x}(\mathrm{R} 2=0.9927)$, take biuret method as the comparison, measured the protein content of 5 samples, together with the results listed in Table 2.

From Table 2, using enzymatic hydrolysis method that milk A, B, E protein content smaller than the biuret method, whiles the milk C, D larger than biuret measured. Therefore, using the t-test tests them, and judge whether there is a significant difference between them. The results showed: calculated $|\mathrm{t}|=0.625$, critical $\mathrm{t}=$ 2.132, calculated $|\mathrm{t}|<$ critical $\mathrm{t}$ value, both measured no significant difference in the results. Moreover, the time of determination of enzyme hydrolysis method only about $8 \mathrm{~min}$, is required $1 / 20$ by biuret method.

\section{Conclusion}

In this experiment, we use the degree of hydrolysis as an index to optimize the hydrolysis conditions of trypsin, the optimal $\mathrm{pH}$ and temperature were 7.5 and $55^{\circ} \mathrm{C}$. And we detected the initial velocity under different casein concentration with the $\mathrm{pH}$-state method. Moreover we get the standard curve $\mathrm{y}=0.1177 \mathrm{x}(\mathrm{R} 2=0.9927)$. In the experiment, we select casein as substrate, because the total casein in milk protein content of more than $80 \%$, and the use of a broad-spectrum enzyme trypsin, which not only hydrolyzed casein in milk and also hydrolyzed some other proteins, such as lactoglobulin and so on. Using this method and the biuret method to detect the protein content of five different brands of fresh milk respectively, the results show that two methods basically consistent; t-test analysis showed no significant difference between them; and the time of former detect process only need 8 min which only is $1 / 20$ of the latter.

\section{References}

Depeters EJ, Ferguson JD. (1992). Non-protein nitrogen and protein distribution in the milk of cows. $J$ Dairy Sci, 1992, 75:3192-3209.

GUO Yong. (2002). Enzyme Engineering. Beijing: China Light Industry Press, 2002:314-315.

JIA Hong-ti. (2005). Biochemistry. Beijing: People’s Medical Publishing House ,2005:92-93.

LI Gui-qin, LIU Jin, HAN Qing-bo. (2003). China Dairy Industry, 2003,31(6):12-13.

LI Pei-jun, YUAN Yong-jun, HU Ting, WANG Li-hui. (2005). Journal of Xihua University, 2005, 25(3):56-57.

LIU Dong-hong,TANG Jia-ni,LV Yuan, YE Xing-qian. (2008). Journal of Chinese Institute of Food Science and Technology,2008,8(5),116-117.

LIU Zhen-xue, HUANG Ren-he, TIAN Ai-ming. (2005). Experimental design and data processing. Beijing: Chemical Industry Press, 2005: 35-36.

MA Ge-li, PENG Xin-bang, WEI Jun, MA Tian-hua. (2007). Food Research and Development, 2007, 28(1):9-10.

NY/T 1678-2008,Determination of Protein in Milk and Dairy Products - biuret method [S].

QIN Li-hu, KOU Yun-juan, REN Jiang-hong, SUN Wu-bin. (2001). Shandong Food Fermentation. 2001,1:33.

TANG Jia-ni, LV Yuan,FU Yu, YE Xing-qian, LIU Dong-hong. (2009). Food and Fermentation Industries.2009, 35(4), 119-120.

TANG Ping, TIAN Jing, SHE Zhen-bao, WENG Qian-feng, XU Guo-wang. (2006). Journal of Analytical Science.2006,22(1):5-8.

WANG Fu-rong,PANG Yu-zhen. (1981). China Condiment,1981,12,21-24.

WANG Zhang. (2005). Food Enzymology. Beijing: China Light Industry Press ,2005:77-79. 
WANG Zheng, YANG Guo-yu, PANG Yu-shan. (2005). Journal of Huazhong Agricultural University, $2005,24(6): 618-621$.

ZHANG Ai-mei, LI Lin-wei, ZANG Yu-bo. (2006). Journal of Analytical Science. 2006,22(1):80.

Table 1. Initial velocity of enzymatic under various casein content

\begin{tabular}{|c|c|c|c|c|c|c|}
\hline $\begin{array}{c}\text { Casein } \\
\text { Content } \\
(\mathrm{mg} / \mathrm{ml})\end{array}$ & 0 & 6.60 & 8.25 & 11.00 & 16.50 & 33.00 \\
\hline $\mathrm{V}(\mu \mathrm{l} / \mathrm{s})$ & 0 & 0.7845 & 1.0751 & 1.2512 & 2.1354 & 3.7728 \\
\hline $\mathrm{RSD}(\% \mathrm{o})$ & 0 & 9.0 & 11.4 & 12.6 & 12.8 & 17.2 \\
\hline
\end{tabular}

Table 2. Comparison of the results based on the two methods

\begin{tabular}{|c|c|c|c|c|c|}
\hline \multirow{2}{*}{$\begin{array}{c}\text { Sample } \\
\text { Numbe } \\
\text { r }\end{array}$} & \multirow{2}{*}{$\begin{array}{l}\text { Sample } \\
\text { Name }\end{array}$} & \multicolumn{2}{|c|}{ Enzyme Hydrolysis Method } & \multicolumn{2}{|c|}{ Biuret Method } \\
\hline & & $\begin{array}{l}\text { Protein Content } \\
(\mathrm{g} / 100 \mathrm{ml})\end{array}$ & $\begin{array}{l}\text { RSD } \\
(\%)\end{array}$ & $\begin{array}{l}\text { Protein } \\
\text { Content } \\
(\mathrm{g} / 100 \mathrm{ml})\end{array}$ & $\begin{array}{l}\text { RSD } \\
(\%)\end{array}$ \\
\hline 1 & Milk A & 3.13 & 12.8 & 3.31 & 12.4 \\
\hline 2 & Milk B & 3.24 & 18.5 & 3.35 & 6.3 \\
\hline 3 & Milk C & 3.42 & 10.2 & 3.28 & 18.3 \\
\hline 4 & Milk D & 3.36 & 7.4 & 3.27 & 11.9 \\
\hline 5 & Milk E & 3.28 & 9.1 & 3.41 & 9.1 \\
\hline
\end{tabular}

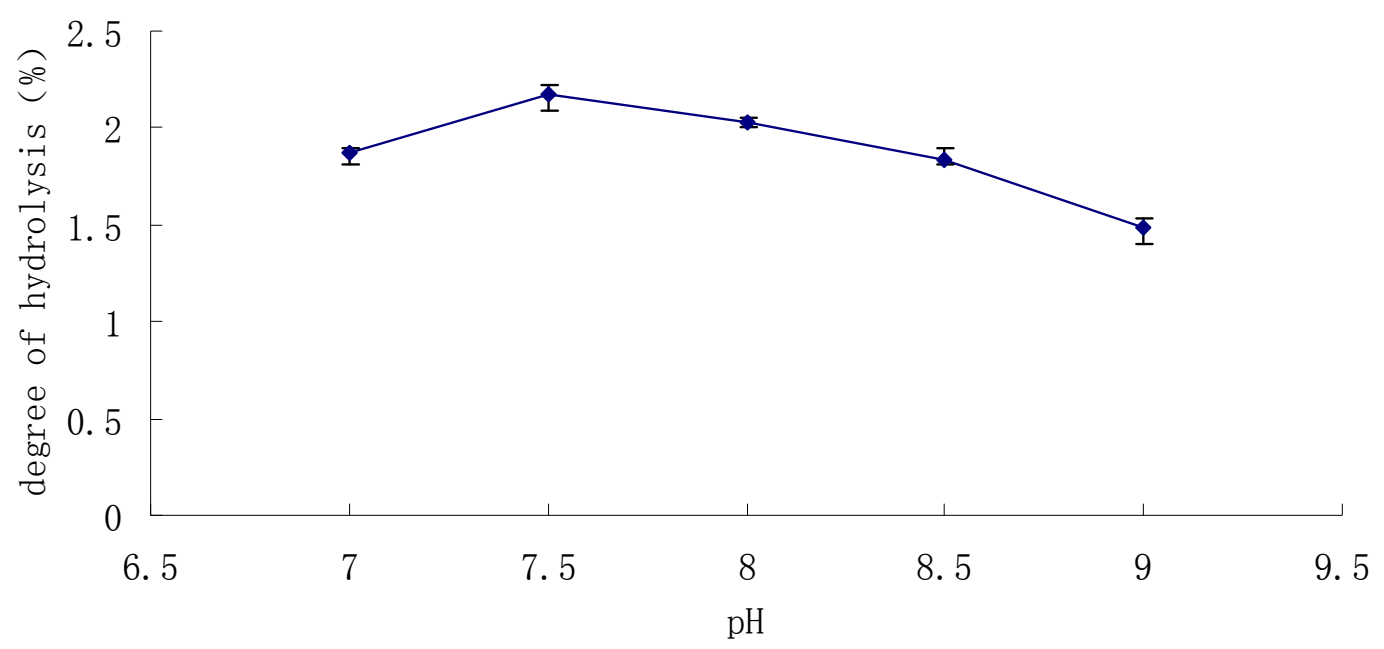

Figure 1. Influence of $\mathrm{pH}$ on the degree of casein hydrolysis 


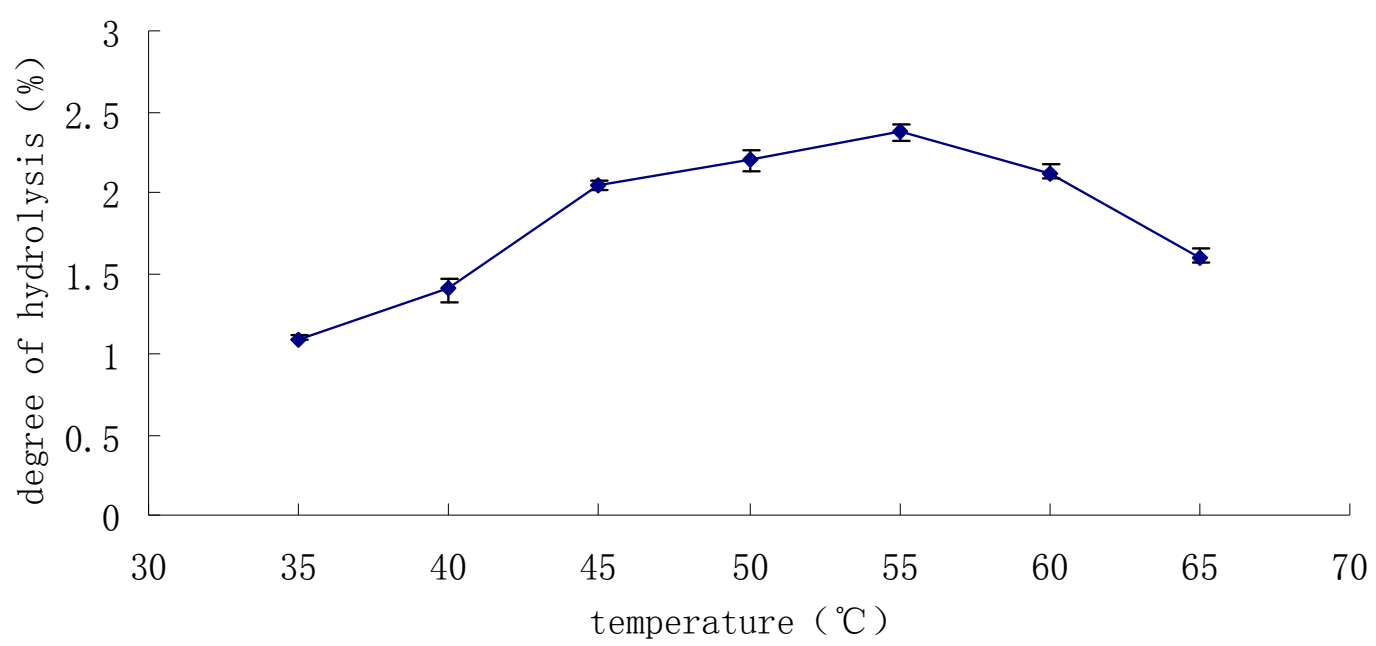

Figure 2. Influence of temperature on the degree of casein hydrolysis

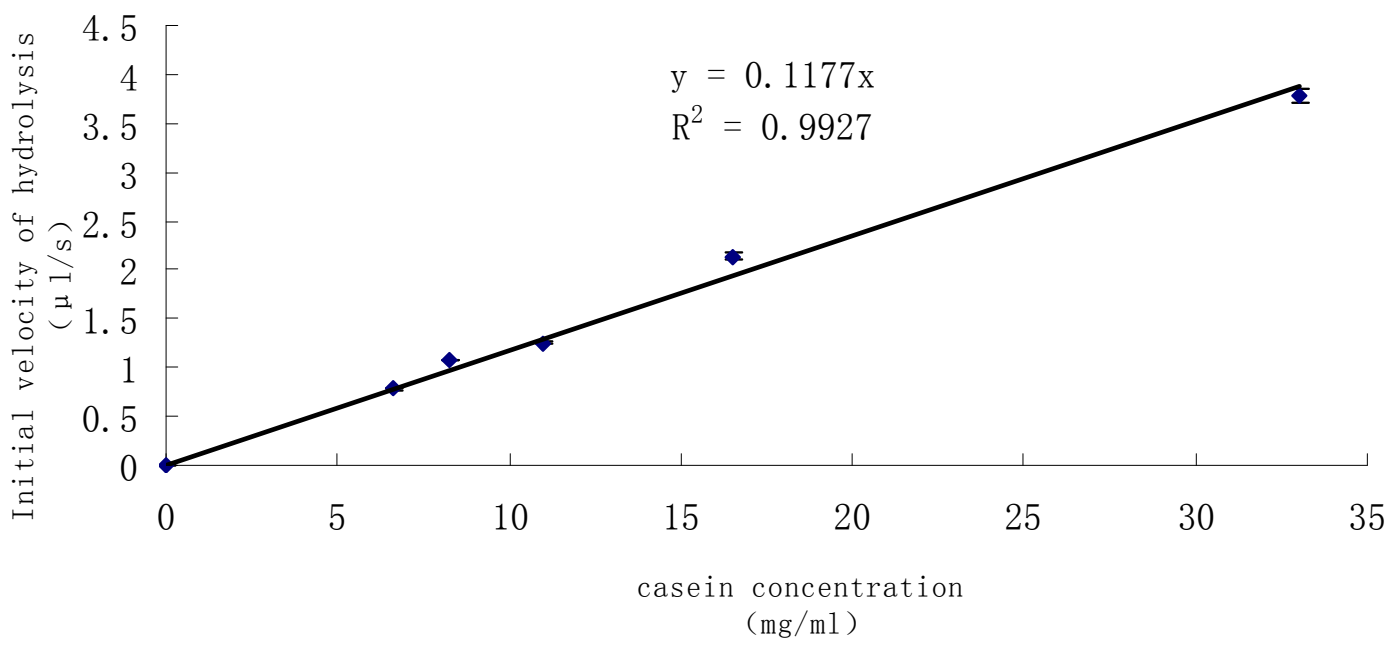

Figure 3. The relation between casein content and initial velocity of enzymatic 